\title{
EU SOU O BIOMA
}

Elara Araújo Moretz-Sohn ${ }^{1}$

Me ataca o estômago

Essas borboletas furiosas e indomáveis

Eu tenho uma floresta inteira dentro de mim

Grandes sapos na garganta

Uma convenção de bichos com asas pelo corpo todo

- Andorinhas, urubus e bem-te-vis -

Formigas nas pernas

- Às vezes é literal -

Elefantes nos pulmões

- Alguns dias são no máximo filhotes de zebras -

Preguiça nas costas

- Ah se fosse só nas costas... -

Onça nas mãos

Gato nos dedos

- É, existe uma leve contradição -

Lebre nos pés

- Sempre tem o momento de jabuti -

E águia nos olhos

- Mas também podem ser só pandas -

- E sim, há uma brincadeira com “águia" e "água” -

Eu tenho uma floresta inteira dentro de mim

Essas borboletas furiosas e indomáveis

Me atacam.

1 Estudante da $2^{\mathrm{a}}$ série do Ensino Médio do Instituto Dom Barreto (IDB), em Teresina (PI). E-mail: elara.moretzsohn@,uol.com.br 